\title{
Using the adsorption chillers for waste heat utilisation from the CCS installation
}

\author{
Karol Sztekler ${ }^{1 *}$, Wojciech Kalawa ${ }^{1}$, Wojciech Nowak $^{1}$, Sebastian Stefański ${ }^{1}$, Jarosław Krzywański ${ }^{2}$ and Karolina \\ Grabowska $^{2}$ \\ ${ }^{1}$ AGH University of Science and Technology, A. Mickiewicza Av. 30, 30-059 Krakow, Poland \\ ${ }^{2}$ Jan Dlugosz University, Armii Krajowej Av. 13/15, 42-200 Czestochowa, Poland
}

\begin{abstract}
Worldwide tendencies in the scope of environmental protection demonstrate the requirement for the limited carbon dioxide emission, that influences on the development of greenhouse effect. As a result of coal as a basic fuel used in the professional power industry, this industry sector is the greatest $\mathrm{CO}_{2}$ polluter and it means that works on the reduction of carbon dioxide in such industry are completely justified. In the IPSEpro programming environment, a reference block model for a conventional coal power station was elaborated, including the $\mathrm{CO}_{2}$ separation unit basing on the adsorption methods with the $\mathrm{CO}_{2}$ preparation installation to liquid state. Simulation researches were conducted with means of numeric techniques, that enabled the system analysis for the $\mathrm{CO}_{2}$ separation unit with the $\mathrm{CO}_{2}$ preparation system to the liquid state, as well as analysis was made for the use of chiller systems, basing on the adsorption technology for waste heat use originating from the compression of $\mathrm{CO}_{2}$ in a cascade system, as well as for potential opportunities for further exploitation of the produced chilled water in the CCS cycle. We analysed in these papers the opportunities for chiller systems application, based on the adsorption chillers in the CCS installation used for the reduction of $\mathrm{CO}_{2}$ emission in the coal power station and its influence on the operation of a power station cycle.
\end{abstract}

\section{Introduction}

Climatic changes have been more and more visible in last years and have been related with the problem of global warming. $\mathrm{CO}_{2}$ is the greatest component of the greenhouse gas emission in percentage value (about 72\% of total emission), then it is methane $\mathrm{CH}_{4}(18 \%)$ and nitrogen monoxide $\mathrm{N}_{2} \mathrm{O}(9 \%)$. According to scientists, carbon dioxide is most harmful for environment and has the greatest influence on the greenhouse effect, thus development of technology limiting the $\mathrm{CO}_{2}$ emission is purposeful [1]. Main mechanisms contributing to the generation of $\mathrm{CO}_{2}$ are processes related with the production of electric power, that are responsible for even $40 \%$ of worldwide carbon dioxide emission. Electric power industry is generally based on the combustion of coal, thus this industry is the largest emitter of $\mathrm{CO}_{2}$. It is expected, that in developed countries the consumption of electric power will increase threefold until 2020, when compared to 1970. Whereas, in developing countries, where the number of citizens may be doubled until 2020, in relation to 1970 , consumption of electric power may increase even twentyfold. It is forecasted in other resources, that until 2030 the yearly increase in demand for electric power will amount to about 2-3\% [2,3].

The problem of $\mathrm{CO}_{2}$ emission is not the problem of explicitly one country, but it pertains to the whole world.
Worldwide economy is developing very rapidly and such development leads to the increased demand for electric power. In order to meet such demand, electric power should be obtained from fossil fuels, what enables its stable and uninterrupted production process. The coal may be still such fuel, with very large resources enabling constant deliveries of electric power. In order to make the energy from the coal the least burdensome for natural environment, the $\mathrm{CO}_{2}$ separation and sequestration technologies should be implemented, that certainly enable the reduction in the emission of such gas. The CCS Technology (Carbon Capture Storage) is based on the separation and sequestration of gas, subsequently its transportation and storage. Limitation of carbon dioxide emission can be pursued with means of the following methods: post-combustion, pre-combustion, oxy-fuel combustion. The $\mathrm{CO}_{2}$ separation before the combustion process is related with initial preparation of the fuel. This fuel is gassed, and after this the synthesis gas is obtained ( $\mathrm{CO}$ and water vapour). In order to obtain the $\mathrm{CO}_{2}$ and $\mathrm{H}_{2}$ streams, the synthesis gas can be treated in the systems based on: processes combined with the conversion of $\mathrm{CO}$ into $\mathrm{CO}_{2}$, processes without the conversion of $\mathrm{CO}$ into $\mathrm{CO}_{2}$, coal gasification in pure oxygen, Integrated Gasification Combined Cycle IGCC. $\mathrm{CO}_{2}$ separation processes after the combustion of fuel. Such technologies are characterised with the separation of carbon dioxide after the combustion

* Corresponding author: sztekler@agh.edu.pl 
process from flue gases. Systems for carbon dioxide separation after the combustion process are separate constructional units, that can be implemented in the existing power units, without interference with theirs construction. The $\mathrm{CO}_{2}$ separation from flue gases can be provided with following methods [4-15]: absorption, adsorption, membrane, cryogenic. The separation system based on the adsorption method is contemplated in this papers. The separation process is not the final step in the $\mathrm{CO}_{2}$ treatment, and the subsequent step is the preparation of separated gas for transportation in liquid form. This process is performed with means of the multi-step compression system, up to the pressure in which the $\mathrm{CO}_{2}$ is changed from gaseous state to liquid state. Between particular compression levels, the waste heat can be utilised and the cold can be produced. When producing the cold, highly efficient and reliable sorption heat recovery technologies can be utilised, such as Adsorption Chillers with desalination function, or Absorption Chillers [16]. The adsorption chiller unit is the industry technical device designed for the production of chilled water and desalinated water with means of low-parameter heat used as a powering energy $\left(60^{\circ} \mathrm{C}-\right.$ $90^{\circ} \mathrm{C}$ ). Principle of operation is detailed in the literature in the broader extent [17-21]. The COP value depends on water temperature leading to the deposit regeneration, as well as on the chilling water, and it is in the range of 0.49-0.56. Such a low COP value is related with low level of thermal conductivity for an adsorbent forming such deposit, as well as its sorption properties [21]. Whereas, the COP is the ratio of heat amount received from evaporation, to the heat amount delivered in the deposit heating step and desorption step, and it is the factor of chilling efficiency:

$$
C O P=\frac{Q_{p}}{Q_{o}+Q_{d}}
$$

Such device provides simultaneous production of chilled water in temperature range: $7-12^{\circ} \mathrm{C}$. The chilled water produced in such devices can be used for airconditioning purposes, or for other technological processes [20].

\section{Developing simulation models}

Installations capturing carbon dioxide on the basis of adsorption processes are not currently operating in full scale in real systems with a power unit. Therefore, we do not have completely documented data, that enables the assessment of its influence on the operation of a power unit. When using the IPSEpro software from SimTech company, we can make models for: a power unit cycle, a carbon dioxide capture process, basing on the mixed PTSA method; a complete technological system for $\mathrm{CO}_{2}$ separation and sequestration, as well as we can make analysis for the chilling installation operation. When basing on data provided in [22], the heat cycle model for a power unit, also called the reference cycle, was developed. Basic parameters for the reference heat cycle are presented in table below.
Table 1. Basic parameters of the reference power cycle [22].

\begin{tabular}{|c|c|c|}
\hline Parameter & Value & Unit \\
\hline Electric power & 833 & $\mathrm{MW}$ \\
\hline Fresh vapour pressure & 266 & $\mathrm{bar}$ \\
\hline Fresh vapour temperature & 554 & ${ }^{\circ} \mathrm{C}$ \\
\hline Fresh vapour mass stream & 625 & $\mathrm{~kg} / \mathrm{s}$ \\
\hline Efficiency of reference cycle & 45.1 & $\%$ \\
\hline Mass flow for furnace flue gases & 1016 & $\mathrm{~kg} / \mathrm{s}$ \\
\hline Mass flow for $\mathrm{CO}_{2}$ & 189.6 & $\mathrm{~kg} / \mathrm{s}$ \\
\hline Fresh vapour pressure & 266 & $\mathrm{bar}$ \\
\hline
\end{tabular}

The $\mathrm{CO}_{2}$ separation system was introduced in the reference cycle, then it was integrated with the whole power unit's cycle. Standard IPSEpro library does not contain the model for the $\mathrm{CO}_{2}$ separation system from flue gases based on the adsorption processes, therefore a numerical model for this process had to be developed, as well as all required balance equations, required from the scope of occurring phenomena. It was assumed, that complete separation process will be described in the form of a single module, that will be available in the form of a single object from the level of IPSEpro software library. The separation module based on the PTSA (Pressure Temperature Swing Adsorption) was accepted for analyses. Detailed description and principle of operation for such module was presented in the following literature $[2,3,7,23]$. It was assumed in the model, that after the separation process, clean carbon dioxide is obtained. The reference cycle diagram including the integrated unit for carbon dioxide capture, altogether with its compression installation, is presented on fig. 1.

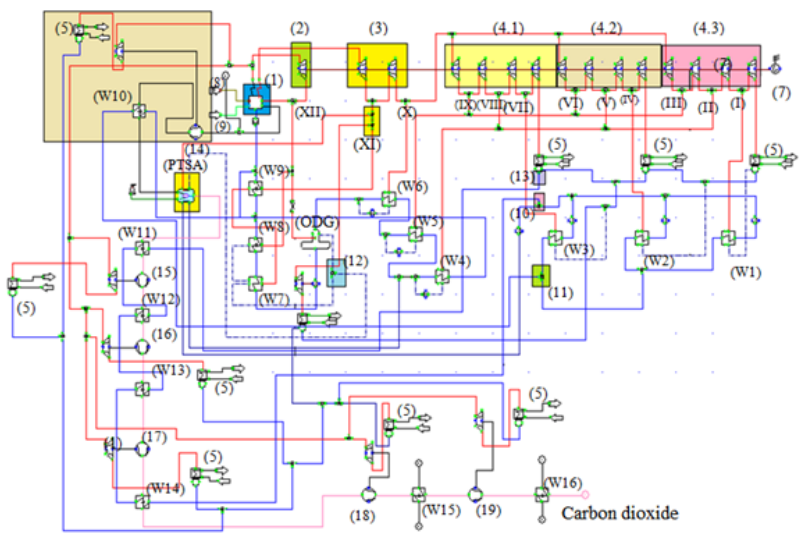

Fig. 1. The reference cycle model with integrated PTSA unit including $\mathrm{CO}_{2}$ preparation system to liquid form.

The released carbon dioxide is guided outside the PTSA system in the amount of about $190 \mathrm{~kg} / \mathrm{s}$, what amounts to $684 \mathrm{t} / \mathrm{h}$ (with $\dot{\mathrm{Q}}_{\text {flue_gases }}=1016 \mathrm{~kg} / \mathrm{s}$ for $100 \%$ 
$\mathrm{CO}_{2}$ separation level). However, in order to make it usable in other industry branches or for storing purposes, it must be transported to destination place in liquid form. The separated carbon dioxide can be prepared for transportation with means of the multi-step compression from 0.15 bar to 100 bar, with means of five used compressors driven by a turbine powered on fresh vapour (15), (16), (17), (18), (19). It is assumed, that the compression level at particular compressor steps will be greater than $\Pi=7$. Before the first compression level (15), carbon dioxide with temperature of $207^{\circ} \mathrm{C}\left(\mathrm{CO}_{2}\right.$ temperature leaving the capturing unit) is cooled down in the exchanger (W11) to temperature of $35^{\circ} \mathrm{C}$, then after each $\mathrm{CO}_{2}$ compression level it is cooled in the exchangers (W12), (W13), (W14) to temperature of $35^{\circ} \mathrm{C}$, and in final step in the exchangers (W15), (W16) to temperature of $25^{\circ} \mathrm{C}$, to liquid form. The exchangers in which the $\mathrm{CO}_{2}$ is cooled down, may be used for the production of hot water guided to the adsorption chillers, after the deposit regeneration process.

\section{Simulation results}

In this section analysis is made for waste heat utilisation from the $\mathrm{CO}_{2}$ preparation installation, until the liquid form. For the purpose of such simulation researches, the followings assumptions are made:

1. Before introducing the flue gases to the $\mathrm{CO}_{2}$ capture system, they must be dehydrated, as well as gaseous contaminants $\left(\mathrm{SO}_{2}, \mathrm{NO}_{\mathrm{X}}\right)$ and solid contaminants must be removed.

2. The $\mathrm{CO}_{2}$ separation unit operates in the fixed state.

3. Adsorption process parameters in the unit PTSA $p=$ 2.0 bar, temperature $\mathrm{t}=110^{\circ} \mathrm{C}$ for desorption $\mathrm{p}=$ 0.15 bar

4. The carbon dioxide separation efficiency from the stream of flue gases amounts to $100 \%$.

5. Powering energy in the form of hot water with temperature of $\mathrm{t}=90^{\circ} \mathrm{C}$ is delivered to the adsorption chiller, with the assumed temperature decrease in the regenerated deposit $\Delta \mathrm{T}=7^{\circ} \mathrm{C}[16,24,25]$.

6. The COP for the adsorption chiller is assumed, $\mathrm{COP}=0.56$, when producing the chilled water with temperature of $\mathrm{t}=12 / 7^{\circ} \mathrm{C}$.

Simulation results demonstrate that altogether with the increased stream of carbon dioxide separated from the flue gases, the amount of generated heat increases (Fig. 2). The amount of generated heat also increases during the $\mathrm{CO}_{2}$ compression and received by a chilling agent from the carbon dioxide $[19,20]$.

For total stream of flue gases and with $100 \%$ separation level $\left(\mathrm{CO}_{2}\right.$ stream $\left.189.6 \mathrm{~kg} / \mathrm{s}\right)$, the heat output transferred to the chilling agent amounts to about 180 $\mathrm{MW}_{\mathrm{t}}$, whereas for $10 \%$ of flue gas stream amount of heat output transferred to the water is about $18 \mathrm{MW}_{\mathrm{t}}$. In table 2 , amount of heat received at particular carbon dioxide chilling steps is presented. Table 2 includes the evaluation for amount of the produced chilled water $\mathrm{t}=$ $12 / 7^{\circ} \mathrm{C}$ and the chillers chilling output at particular $\mathrm{CO} 2$ chilling steps, as well as the production of hot water $90 / 83^{\circ} \mathrm{C}$ used in the regeneration process.

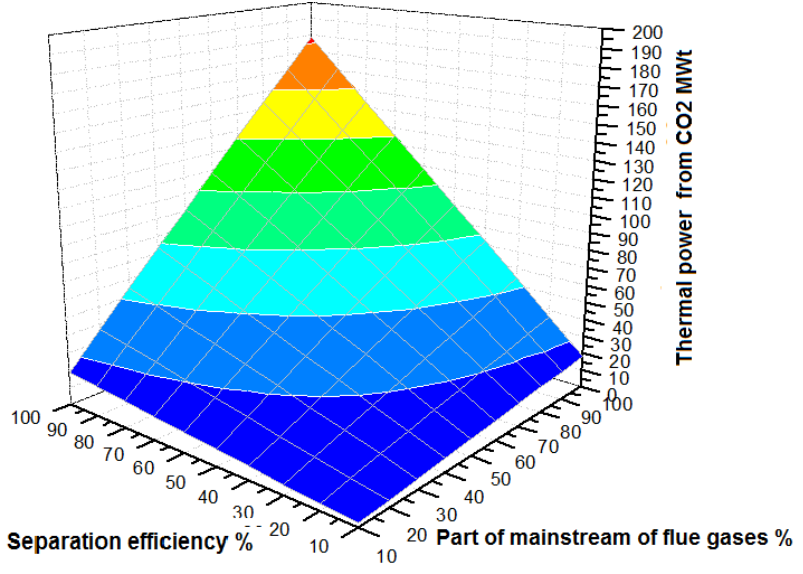

Fig. 2. Total heat output received from the $\mathrm{CO}_{2}$ during its chilling.

Table 2. Heat recovery from particular $\mathrm{CO}_{2}$ chilling steps.

\begin{tabular}{|c|c|}
\hline $\begin{array}{l}\text { Heat received } \\
\text { from } \mathrm{CO}_{2} \text { after } \\
\text { the first chilling } \\
\text { step (W11) }\end{array}$ & $\begin{array}{l}\text { Heat received from } \mathrm{CO}_{2} \mathrm{Q}_{\mathrm{re} \cdot}=28 \mathrm{MW}_{\mathrm{t}} \\
\text { Hot water stream } \mathrm{m}_{\mathrm{h}}=918.67 \mathrm{~kg} / \mathrm{s} \\
\text { Chilled water stream } \mathrm{m}_{\mathrm{ch}}=747 \mathrm{~kg} / \mathrm{s} \\
\text { Chiller's chilling output } \mathrm{Q}_{\mathrm{ch}}=15.68 \mathrm{MW}_{\mathrm{ch}}\end{array}$ \\
\hline $\begin{array}{l}\text { Heat received } \\
\text { from } \mathrm{CO}_{2} \text { after } \\
\text { the second } \\
\text { chilling step } \\
\text { (W12) }\end{array}$ & $\begin{array}{l}\text { Heat received from } \mathrm{CO}_{2} \mathrm{Q}_{\mathrm{re}}=29 \mathrm{MW}_{\mathrm{t}} \\
\text { Hot water stream } \mathrm{m}_{\mathrm{h}}=986.72 \mathrm{~kg} / \mathrm{s} \\
\text { Chilled water stream } \mathrm{m}_{\mathrm{ch}}=774.2 \mathrm{~kg} / \mathrm{s} \\
\text { Chiller's chilling output } \mathrm{Q}_{\mathrm{ch}}=15.68 \mathrm{MW}_{\mathrm{ch}} \\
\mathrm{Q}_{\mathrm{ch}}=16.24 \mathrm{MW}_{\mathrm{ch}}\end{array}$ \\
\hline $\begin{array}{l}\text { Heat received } \\
\text { from } \mathrm{CO}_{2} \text { after } \\
\text { the third } \\
\text { chilling step } \\
\text { (W13) }\end{array}$ & $\begin{array}{l}\text { Heat received from } \mathrm{CO}_{2} \mathrm{Q}_{\text {re. }}=29 \mathrm{MW}_{\mathrm{t}} \\
\text { Hot water stream } \mathrm{m}_{\mathrm{h}}=986.72 \mathrm{~kg} / \mathrm{s} \\
\text { Chilled water stream } \mathrm{m}_{\mathrm{ch}}=774.2 \mathrm{~kg} / \mathrm{s} \\
\text { Chiller's chilling output } \mathrm{Q}_{\mathrm{ch}}=16.24 \mathrm{MW}_{\mathrm{ch}}\end{array}$ \\
\hline $\begin{array}{l}\text { Heat received } \\
\text { from } \mathrm{CO}_{2} \text { after } \\
\text { the fourth } \\
\text { chilling step } \\
\text { (W14) }\end{array}$ & $\begin{array}{l}\text { Heat received from } \mathrm{CO}_{2} \mathrm{Q}_{\mathrm{re} \cdot}=21 \mathrm{MW}_{\mathrm{t}} \\
\text { Hot water stream } \mathrm{m}_{\mathrm{h}}=714.52 \mathrm{~kg} / \mathrm{s} \\
\text { Chilled water stream } \mathrm{m}_{\mathrm{ch}}=560.6 \mathrm{~kg} / \mathrm{s} \\
\text { Chiller's chilling output } \mathrm{Q}_{\mathrm{ch}}=11.76 \mathrm{MW}_{\mathrm{ch}}\end{array}$ \\
\hline $\begin{array}{l}\text { Heat received } \\
\text { from } \mathrm{CO}_{2} \text { after } \\
\text { the fifth chilling } \\
\text { step (W15) }\end{array}$ & $\begin{array}{l}\text { Heat received from } \mathrm{CO}_{2} \mathrm{Q}_{\mathrm{re} .}=40 \mathrm{MW}_{\mathrm{t}} \\
\text { Hot water stream } \mathrm{m}_{\mathrm{h}}=1361 \mathrm{~kg} / \mathrm{s} \\
\text { Chilled water stream } \mathrm{m}_{\mathrm{ch}}=1068 \mathrm{~kg} / \mathrm{s} \\
\text { Chiller's chilling output } \mathrm{Q}_{\mathrm{ch}}=22.4 \mathrm{MW}_{\mathrm{ch}}\end{array}$ \\
\hline $\begin{array}{l}\text { Heat received } \\
\text { from } \mathrm{CO}_{2} \text { after } \\
\text { the sixth } \\
\text { chilling step } \\
\text { (W16) }\end{array}$ & $\begin{array}{l}\text { Heat received from } \mathrm{CO}_{2} \mathrm{Q}_{\mathrm{re}}=28 \mathrm{MW}_{\mathrm{t}} \\
\text { Hot water stream } \mathrm{m}_{\mathrm{h}}=918.67 \mathrm{~kg} / \mathrm{s} \\
\text { Chilled water stream } \mathrm{m}_{\mathrm{ch}}=1068 \mathrm{~kg} / \mathrm{s} \\
\text { Chiller chilling power } \mathrm{Q}_{\mathrm{ch}}=15.68 \mathrm{MW}_{\mathrm{ch}}\end{array}$ \\
\hline
\end{tabular}

\section{Summary}

Following the collected data it is determined, that heat recovery at particular carbon dioxide chilling steps and the production of chilled water in amount of $\mathrm{m}=4.67 \mathrm{t} / \mathrm{s}$ is possible, what conforms with $100 \mathrm{MW}_{\text {ch }}$ total chilling output. According to data [22], currently the largest manufactured adsorption chillers have $2 \mathrm{MW}_{\mathrm{ch}}$ output, what means that 50 such units should be installed, in order to capture the heat coming from the $\mathrm{CO}_{2}$ 
compression. In the analysed case, we cope with polygeneration, because the production of electric power, heat, cold and $\mathrm{CO}_{2}$ takes simultaneously place, and the $\mathrm{CO}_{2}$ may be treated as useful product. The capture system in which $100 \%$ of carbon dioxide separation is provided from total stream of flue gases produced by a power unit with nominal power of 833 $\mathrm{MW}_{\mathrm{e}}$ (the reference unit modelled according to the Belchatow Power Plant power unit) [26], including devices for technical execution of the adsorption, desorption, compression and $\mathrm{CO}_{2}$ condensation process, generates about $16 \%$ decrease in the heat cycle efficiency and about $350 \mathrm{MW}_{\mathrm{e}}[3,23]$ demand for the energy necessary for complete carbon dioxide sequestration. Additional product in form of the chilled water is produced in the adsorption chillers and can be sold or reused in other industrial processes, and the utilised waste heat should contribute to the increased efficiency of chemical energy coming from fuel in the production of electric power in such power plant. In the EU-15 countries in 2000, 27\% of office spaces and 5\% of houses were cooled. Following data analysis for such 15 EU countries, it is assumed that target share of cooled space (,the European saturation rate") in the residential objects will amount to $40 \%$, whereas in office objects it will be $60 \%$. It is evaluated, that this level will be obtained in 2012. In Poland, such conditions can be achieved in a significantly later period, namely about 2020. According to forecasts presented in the work [27], demand for cold will amount to $5000 \mathrm{MW}_{\mathrm{ch}}$ in 2020 in Poland. One power plant with CCS, in which the heat recovery systems from carbon dioxide chilling installations are installed, can satisfy $2 \%$ demand for total cold production in Poland in 2020. Another step in such analysis is evaluation for the influence of waste heat utilisation installations on the operation of CCS installation, and on the operation of power unit.

\section{Acknowledgment}

The paper was funded from government money Faculty of Energy and Fuels number 11.11.210.216.

\section{References}

1. K. Pikoń, M. Kajda-Szcześniak, M. Bogacka, Przemyst Chemiczny 941548 (2015)

2. K. Sztekler, W. Kalawa, M. Panowski, Energy Policy J. 17137 (2014)

3. K. Sztekler, W. Kalawa, M. Panowski, R. Klajny, Instal 1217 (2013)

4. J. Kotowicz, K. Janusz, Rynek Energii 1 (2007)

5. I. Majchrzak-Kucęba, W. Nowak, Proc. of the 2nd Int. Conf. on Contemporary Problems of Thermal Enginnering 641 (2004)

6. L. Szczygieł, Biuletyn Urzędu Regulacji Energetyki 5 (2007)

7. K. Sztekler, M. Panowski, R. Klajny, Prace Naukowe Politechniki Warszawskiej 26317 (2009)
8. M. Mazurkiewicz, A. Uliasz-Boheńczyk, E. Mokrzycki, Z. Piotrowski, R. Pomykała, Polityka Energetyczna 8527 (2005)

9. J. Rakowski, Energetyka 4 (2010)

10. R. Lensen, The promoter effect of piperazine on the removal of carbon dioxide (2004)

11. S. Chakravarti, A. Gupta, B. Hunek, Proc. of First National Conf. on Carbon Sequestration (Washington DC, 2001)

12. T. Czakiert, K. Sztekler, S. Karski, Fuel Processing Technology 911617 (2010)

13. J. Rolker, M. Seiler, Adv. in Chemical Eng. and Science 1280 (2011)

14. F. Colin, $\mathrm{CO}_{2}$ Capture With MEA: Integrating the Absorption Process and Steam Cycle of an Existing Coal-Fired Power Plant, (Waterloo, Ontario, Canada, 2004)

15. M. Wanga, A. Lawala, P. Stephensonb, J. Siddersb, C. Ramshawa, H. Yeunga, Chem. Engineering Research and Design 891609 (2011)

16. R. Wang, L. Wang, Wu J, Adsorption Refrigeration Technology: Theory and Application (2014)

17. K. Sztekler, M. Komorowski, M. Tarnowska, Ł. Posak Proc. of the Int. Conf. on the Sustainable Energy and Environment Development, E3S Web of Conferences 10 (2016)

18. K. Sztekler, K. Wojciechowski, M. Komorowski, M. Tarnowska, Proc. of Energy and Fuels Conf., E3S Web of Conferences 14 (2016)

19. K. C. Ng, B. B. Saha, Advances in Adsorption Technology (2010)

20. M. Chorowski, Nowa Energia 4 (2014)

21. M. Gwardera, K. Kupiec, Inż. Ap. Chem., 5038 (2011)

22. http://www.net-sa.eu/ (2017)

23. K. Sztekler, T. Siwek, M. Komorowski, Problemy Energetyki i Ochrony Środowiska 62111 (2013)

24. X. Wang, H.T. Chua, Int. J. of Refrig. 301417 (2007)

25. Q. W. Pan, R. Z. Wang, L. W. Wang, D. Liu, Int. J. of Refrig. 67336 (2016)

26. EPConstruction Sp. $\mathrm{z}$ o.o.: Building project of 833MW power unit for BOT Elektrownia Betchatów SA, Z-398, 3, The environmental impact assessment report, Technical description 01 (2005)

27. UCB Energ. I Ochr. Środ., ITC Politechniki Śląskiej, ARE S.A., Raport z II etapu pracy: Analiza krajowego potencjatu wysokosprawnej kogeneracji (2007) 